\title{
Criterion of Client's Company, Public Accountant Firm, Financial Distress, and Company Growth Towards Auditor Switching
}

\author{
Annisa Adha Minaryanti \\ annisa_minaryanti@yahoo.com \\ R. Muchammad Noch \\ University of Pasundan
}

\begin{abstract}
There were some factors why company switched its auditor voluntarily, that were criterion of client's company, criterion of public accountant firm, financial distress, and company growth. Population in this study was a manufacture company's financial report in the sector of Basic and Chemical Industry, by the amount of 65 companies listed in Indonesia Stock Exchange in the period of 20102015. A method used was purposive sampling that is 13 companies. The analytical tool used is logistic regression analysis. The results showed that the criterion of client's company and company growth statistically did not give any influence towards auditor switching. Meanwhile, the criterion of public accountant firm and financial distress did give influence towards auditor switching.
\end{abstract}

Keywords: criterion of client's company, criterion of public accountant firm, financial distress, company growth, auditor switching

\section{INTRODUCTION}

Auditor switching was an activity undertaken by a company to switch auditors due to its audit rotation. Based on theoretical evidence, rotating auditor caused the shorter period of audit tenure in which company would undertake auditor switching (Nasser et al, 2006:4).

In Indonesia, there were regulation which governs audit tenure, that was the Decree of Minister of Finance of Republic of Indonesia No. 359/KMK.06/2003 article 2 on "Public Accounting Services". The regulation itself was a change of the Decree of the Minister of Finance No. 423/KMK.06/2002 stipulating that the provision of general audit services to the financial reports of an entity might be executed by the public accountant firm for a maximun of five consecutive years and by the public accountant fo three consecutive years. The regulation was then renewed and amended by the issuance of Regulation of the Minister of Finance of Republic of Indonesia No. 17/PMK.01/2008 Section 3 concerning on "limitation of public accountant practices and public accountant firm". This regulation covered about the provision of general audit services to the financial reports of an entity which was undertaken by public accountant firm for a maximum of six consecutive years and by the public accountant for three consecutive years. Both public accountant and its firm might reoperate after a year.
Auditor rotation was not only practically done mandatorily, but also voluntarily. Voluntary auditor switching could happen if the client switch her/his auditor without anyone's rule or permission to do it.

Mandatory auditor switching and voluntary auditor switching could be distinguished based on the focus of each party. If the auditor was voluntarily switched, the focus would be on the client. Otherwise, if the auditor was mandatorily switched, the focus would be on the auditor (Febrianto, 2009). When the client switched the auditor and if there was no regulation about it, it would cause two things: the auditor would either resign or be fired by the client. Of which those things happened, the focus would be on the reason why it happened and where the client went through.

In Indonesia, auditor switching was ideally undertaken mandatorily. However, the fact of auditor switching in Indonesia showed us that there was company which undertook it voluntarily (Yanwar: 2012). A voluntarily auditor switching affected some negative impacts towards the company due to its frequent switch of auditors. The impact included higher cost on the money because the company itself would spend more if it still hired the same auditor. For example, first thing that a new auditor of a company might do was to understand the client's work environment and to determine audit risk. For the auditor who had not already understood the environment yet, he/she would need a higher start-up cost, which could finally rise his/ 
her audit fee. Other than that, auditors who performed their duties in the early years proved to have a high probability of errors.

The other impacts of frequent switch of auditor is seen by the client's point of view: that, more or less, the auditor who performs in their first year will interfere the other employee's comfort, by asking several questions about the company that should not be asked if the auditor does not switch. American Institute of Certified Public Accountants (AICPA) (1992) stated that the disadvantage of auditor rotation is that the knowledge gained during the quality improvement of audit work will be useless with the recruitment of a new auditor. In other words, the audit quality will also decrease.

There are some factors why company switch auditors voluntarily; that is because the criterion of client's company. A bigger auditee company will need a public accountant firm which is capable of reducing agency cost (Watts and Zimmerman, 1990, cited by Mutiara, 2012) and threat of auditor's personal interest (Hudaib and Cooke, 2005). Other than that, the firm should also have a high independency due to the rise of determination between principal and agent, and also due to its operational complexity. Due to the size of firms which are large, the number of possible conflicts of agent is also high. It can also increase a qualified auditors.

The second factor which caused client switched the auditor was the criterion of public accountant firm. DeFond (1992) as cited by Wijaya (2013) stated that the audit quality could also be determined by by the size of the public accountant firm itself. The firm which had smaller size had smaller resources, which were then perceived to be in a lower quality.

The third factor which caused client switched the auditor was the financial distress. It was a first stage of company's bankruptcy. Financial distress could also be defined as "a company's financial condition which ran into a severe liquidity, therefore the company itself was not able to operate properly. The definition of financial distress was often closely related to bankruptcy" (Irvan and Tri: 2014). Bankruptcy was usually defined as a failure of the company in carrying out its operational activities to generate profit and also a failure in paying obligations. Bankruptcy was also often called liquidation or corporate closure or insolvability.

The fourth factor which caused client switched the auditor was the company growth. One of the ways to find out or measure the company growth was to observe the sales, because it was the main important thing for a company to observe. If the sales was increasing, then the company growth would also increase. Otherwise, if the sales was decreasing, then the company growth would also decrease. This was also supported by Sihombing (2012) who stated that "One of the indicators of company growth was the sales, because it was the main operational activity of an auditee". Generally, company that had a positive sales growth rate indicated the company's ability to maintain its viability.

If the company grwoth was increasing, then the profit gained would also increase. Also if the company growth was increasing, it would have an impact on the company's need for a qualified auditor, as it was followed by an increased need and rapid company demands. If this could not be fulfilled by an auditor, the auditor him/herself would probably switch his/her firm (Sihombing:2012).

The emergence of a study on auditor switching was backgrounded by several cases of companies that switched auditors frequently, meaning that the company has already changed the public accountant firm more than two times within the period of research (five years). This changing happened to manufacture company in the sector of Basic and Chemical Industry, such as PT Jakarta Kyoei Steel Works Tbk and PT Kertas Basuki Rachmat Indonesia Tbk.

Within five years, PT Jakarta Kyoei Steel Works Tbk had already changed its firm four times: in 2011 by using the firm of Muhammad Sofwan and Partners; in 2012 by using the firm of Gideon Ikhwan Sofwan; in 2013 by using the firm of S. Mannan Ardiansyah and Partners; and in 2014 and 2015 by using the firm of Abubakar, Usman, and Partners.

Furthermore, PT Kertas Basuki Rachmat Indonesia Tbk had already changed its firm three times within five years; in 2011, 2012, and 2013 by using the firm of Hananta Budianto and Partners; in 2014 by using the firm of Tanubarta Sunanto Fahmi and Partners; and in 2015 by using the firm of Hendrawinata Eddy Siddharta and Tanzil.

Seen from the cases above, there were several factors effecting companies switcth their Public Accountant Firm more than two times within five years. Therefore, this study will discuss more about those factors.

This research referred to previous research, especially to those which have been done by Prastiwi and Wilsya (2009). This was taken to retest whether the variables used by Prastiwi and Wilsya were still relevant if they were reobserved for the next six years. However, there were some differences between this research and the previous ones, that were: (1) Prastiwi and Wilsya (2009) did not observe about variables of Audit Opinion, like what I observe now, (2) This research did not focus on variables of Income Changing, like what Prastiwi and Wilsya did.

Hypothesis Development, $\mathrm{H}_{1}=$ Criterion of Client's Company gave influence towards Auditor Switching, $\mathrm{H}_{2}$ $=$ Criterion of Public Accountant Firm gave influence towards Auditor Switching, $\mathrm{H}_{3}=$ Financial Distress gave influence towards Auditor Switching, $\mathrm{H}_{4}=$ Company Growth gave influence towards Auditor Switching.

Auditor switching was an activity undertaken by a company to switch auditors due to its audit rotation. Based on theoretical evidence, rotating auditor caused 
the shorter period of audit tenure in which company would undertake auditor switching (Nasser et al, 2006:4).

In accepting an engagement, an auditor had professional responsibility to the community, clients, and other members of the public accountant. Therefore, the decision to accept a new audit client or continue a relationship with an existing client should not be underestimated (Aurora: 2013).

An auditor needed to pay his/ her attention carefully on every audit assignemnts, especially a new client's audit. This new client could be divided into two client: 1) a client that had never been audited and 2) a client that was removed from other firms. An auditor should firstly and fully understand the background and information related to the client's business entity in order to get a fully and proper understanding/agreement before signing the contract of audit assignment (Aurora : 2013).

The company which had switched auditot would incure cost that should not be incurred if it continued to hire the same auditor. For example, first thing that a new auditor of a company might do is to understand the client's work environment and to determine audit risk. For the auditor who had not already understood the environment yet, he/she would need a higher start-up cost, which could finally rise his/her audit fee. Other than that, auditors who performed their duties in the early years proved to have a high probability of errors (Pratitis, 2012:28).

The other impacts of frequent switch of auditor was seen by the client's point of view: that, more or less, the auditor who performed in their first year would interfere the other employee's comfort, by asking several questions about the company that should not be asked if the auditor did not switch. American Institute of Certified Public Accountants (AICPA) stated that the disadvantage of auditor rotation was that the knowledge gained during the quality improvement of audit work would be useless with the recruitment of a new auditor. In other words, the audit quality would also decrease.

The client would switch his/her auditor when there are no regulation that required the replacement to take place. What happened next included twho things: first was either that auditor would resign or be fired by the client. Any of which happened, the focus would be on the reason why it happened and where the client would continue to move. If the reason of the replacement was due to the disagreement over certain accounting practice, the client was expected to move to other auditors who had same agreement.

The criterion of client's company was a scale of company's financial condition which was also often classified as a scale of company's criterion. Large companies were believed to be able to solve financial problems they are running in better than small companies (Mutchler: 1985 cited by Aurora: 2013).

A large company usually provided more information for investor in making decision related to the stock investment in the company. Abretch and Richardson (1990) and Lee and Choi (2002) cited by Mutiara (2012) found that the larger company generally had less motivation to share profit evenly compared to small company, because large company was viewed more critical by outside party. Therefore, it tended to show that the company's criterion gave influence to the profit of company's management. There were two possibilities that might happen: 1) when the profit management was opportunist: the larger the company was, the smaller the profit management; 2) when the profit management was efficient: the larger the company was, then the higher the profit management.

Other than that, a large auditee company needed a high-independent audit company to reduce the agency cost because of its operational complexity and its rise of determination between principal and agent (Mutiara:2012).

According to the Law of Republic of Indonesia No. 5/ 2001, a public accountant firm was defined as:

"[a] business entitites established under the provisions of legislation. It also obtains business licenses based on the Act as a forum for public accountants in providing services."

One of the public accountant firm's roles in the company was to provide attestation services on the company's financial statements (Mutiara: 2014). An opinion given by the auditor on the company's financial statements included the fairness of presentation of financial statements based on the general accounting principles. Opinions given by the auditor would increase the confidence of the interested parties over the information presented by the company.

DeAngelo (1981) cited by Mutiara (2012) explained that the audit quality undertaken by public accountants could be rated by the criterion of public accountant firm which undertook the audit process.

The criterion of public accountant firm could be measured by the number of partners, auditors, clients, and income (Riska and Betri: 2014). Halim (2008, p. 16) cited by Riska and Betri (2014) stated several things about organization staff in public accountant firm, as followed: (a) Partner was a top legal client relationship. $\mathrm{He} /$ she reviewed the audit, signed the audit statements, approved the fee and billings and was responsible for everything related to audit work. (b) Manager was a staff who more or less interacted with client, oversaw the execution of audit assignments, reviewed more details of audit works, and collected billings on audit fees. (c) Senior accountant was a direct responsible staff for planning and conducting the audit work, and reviewing the work of junior accountants. (d) Junior accountant was a responsible staff for field work. The junior's assigment might be some parts of the audit work; and if possible, the juniors might give an opinion on the part of the examination. 
Financial distress was a first stage of company's bankruptcy. Financial distress could also be defined as "a company's financial condition which ran into a severe liquidity, therefore the company itself was not able to operate properly. The definition of financial distress was often closely related to bankruptcy" (Irvan and Tri: 2014). Bankruptcy was usually defined as a failure of the company in carrying out its operational activities to generate profit and also a failure in paying obligations. Bankruptcy was also often called liquidation or corporate closure or insolvability.

Financial distress could be caused by several factors. The beginning of financial distress started when the company's cash flow was less than the amount of longterm debt that had matured (Irvan and Tri: 2014). This reflected that the company was unable to meet the payment of the obligations that should be paid on the spot.

Sudana (2011: 249) stated that the factors of financial distress was due to economic factors, errors in management, and natural disasters. Companies that failed in their operations would have an impact on financial distress. But most of the causes of financial distress, either directly or indirectly,were due to repeated management mistakes.

An analysis model called Z-score in its original form was a linear model with weighted financial ratios in order to maximize the model itself in identifying several kinds of financial ratios considered to have an important value in giving influence to an event or phenomenon leading to company's bankruptcy. Based on these events, a development was then carried out into a model that aimed to facilitate in drawing a conclusion of an event.

This Z"-score model gave an average score of groups of companies which did not go bankrupt to become slower compared to the second bankruptcy model. To predict whether a company in a developed company had a potential of bankruptcy, Altman also set discriminant area. This condition could be seen from the value in Z"-score, if: (a) The value of Z"'-score was less than 1.1 , it meant that the company was running a financial problems and its risk was high. (b) The value of Z"-score was between 1.1 and 2.60, it meant that the company was considered vulnerable. In this condition, the company was in a state of financial problems and should have been anticipated by making a right and proper decision. If the decision-making was late concluded, the company was in bankruptcy. (c) The value of Z"-score was more than 2.60 , it meant that the financial condition in the company was really good, so that the banktruptcy possibility was low.

Kallamput and Trombey (2001) cited by Mutiara (2012) stated that a growing company was a company which had the ability to increase size. The company growth was basically influenced by several factors: external and internal, and local industry climate. In relation to leverage, companies with high growth rates should use equity as a source of finance to avoid spending agency cost between shareholders and company management. Whereas companies with low growth rates should use debt as a source of finance because the debt use would require the company to pay interest on a regular basis.

A rapid growth of the company would require funds to do expansion. The bigger the need to spend, the bigger the company's will to press profit. Therefore, a growing company should not share any profit as dividend, but to use it to do an expansion. The growth potential could be measured from its research and development cost.

The company growth could be measured by some ways. One of it was by overseeing its sales growth, such as described in this study.

In this study, the growth of client's companies was calculated by using the company's client growth ratio: that was a current net sales reduced by last year's net sales, then divided by total assets (Weston and Copeland: 1992, cited by Mutiara: 2012).

\section{METHOD}

Population was a manufacture company's financial report in the Sector of Basic and Chemical Industry, by the amount of 65 companies listed in Indonesia Stock Exchange in the period of 2010-2015. During these five years, the determination of population was based on the Regulation of the Minister of Finance concerning the auditor switching that regulated the audit service by the Public Accountant Firm for six consecutive years. Therefore, this study examined up to one auditor switching.

A sampling determination method used in this study was included in purposive sampling because the criterias had already been determined. About thirteen companies would be the samples of companies. Data collected by literature research, documentation, and online research. Logistic regression analysis was used.

\section{RESULTS AND DISCUSSION}

From the calculation result can be known that the average size of companies in manufacturing companies tend to fluctuate with a downward trendline. The average number of large companies listed on the IDX from 2011-2015 shows that the size of the company in 2011 is 26.66 and then decreases in 2012 to 26.00 and in 2013 rose to 26.05, but in 2014 declined to 26.02. In 2015, the size of the company has increased significantly to 26.49. The results show that, on average of all size of the company, which means that if the amount of assets owned by a large company then the company entered into a large company class, and vice versa.

From the calculation, it can be seen that as much as $80 \%$ of the company's data is recorded as affiliated 
with the big four public accountant firm, while the remaining $20 \%$ is affiliated with non big four public accountant firm. This shows that, from 13 manufacturing companies listed on the IDX, most of them use auditor from The Big Four.

From the calculation results can be seen that the average financial distress in manufacturing companies have an increasing trendline. The beginning of 2011 they have a healthy company condition with a number of 8.91, in 2012 has increased by 9.02, in 2013 the companies' health has increased considerably that is 9.40, and in 2014 and 2015, the health of companies experienced a slight decline but still higher than in 2011 and that is shown at 9.37 and 9.42. even in 2015 is still higher than in 2013.

Based on the calculations, the average growth of manufacturing companies tend to decrease each year. The beginning of 2011 the growth of the companies showed of 0.07 , in 2012 the growth of the companies decreased by 0.02 , in 2013 the companies' growth have increased as in 2011 that is 0.07 and in 2014 down to 0.04 , while in 2015 the companies' growth have decreased to -0.06 .

From the calculation result, sig value obtained is 0.860 and greater than 0.05 , so with a $95 \%$ confidence level can be decided to accept Ho and reject Ha or in other words company size has no significant influence on auditor switching. This research fails to show any influence of the client's company size towards auditor switching, and rejects opinions of Watts and Zimmerman (1990) cited by Mutiara (2012) that larger auditee companies are in the need of a public accountant firm that can reduce agency costs. The results of this study are also not in line with Francis et al. (1988) cited by Aurora (2013), Naaser et al. (2006), and Suparlan and Andayani (2010) where the results of their research indicate that the size of the client company has a significant influence on the selection of public accounting firm.

Clients with small total assets tend to move to a non-big four public accountant firm, while issuers with large total assets still choose big 4's public accountant firm as their auditor, reflecting the suitability of the size between the firm and its clients. Most of the study sample consisted of clients with a small asset total and most of them were already using non-big 4 public accountant firms, therefore there was no tendency to do auditor switching.

From the calculation result, sig value obtained is 0.003 and smaller than 0.05 , so with a $95 \%$ confidence level it can be decided to reject Ho and accept Ha or in other words public accountant firm size has a significant influence on auditor switching.

The results of this study accept the opinion that has been proposed by DeFond (1992) cited by Wijaya (2013) that audit quality can also be determined by the size of the public accounting firm itself. Small firms have smaller resources, which are perceived to be of lower quality.

The results of this study are also in line with research conducted by Mardiyah (2002); Nasser, et al. (2006); Damayanti and Sudarma (2008); and Wayan and Ketut (2013) that there is aninfluence of public accountant firm size on auditor switching.

The size of public accountant firm becomes one of the factors that encourage auditor switching because public accountant firm size reflects better reputation and quality (Pangky: 2011). The size of public accountant firm also determines the credibility of the auditor. Therefore, companies that cooperate with big four's public accountant firm will rarely make a change of auditors.

The results, showed that financial distress has a significant influence on auditor switching. The results of this study accepted the opinion of Sihombing (2012), that the company's financial condition may have important implications on the decision to retain public accountant firm.

The results of this study are also in line with Schwartz and Soo (1995) cited by Sihombing (2012) concluded that companies experiencing financial difficulties or financial distress more are often do auditor switching than companies that do not experience financial distress. The condition of client's companies that are experiencing financial difficulties and threatened with bankruptcy tend to have an impact on the increase of caution and evaluation of auditor's subjectivity, because if a company that experienced bankruptcy chooses the wrong public accountant firm, it will worsen the condition of the company.

The company growth has a significant influence on auditor switching. The results received an opinion from Sihombing (2012) which stated that if the growth of the company is increasing then the profits will increase. Usually if the company is experiencing growth, it will also affect the company's need for quality auditors, as followed by increasing needs and fast demands from company. If this is not met by the auditor, it is likely that the company will replace public accountant firm.

\section{CONCLUSION}

Test results and discussion in the previous section can be summarized as followed: (1) The result of logistic regression analysis shows that statistically client'scompany size does not have an influence on auditor switching. (2) The result of logistic regression analysis shows that statistically Public Accountant Firm size has an influence to auditor switching. (3) The result of logistic regression analysis shows that statistically client's company's growth rate does not have an influence on auditor switching. (4) The result of logistic regression analysis result shows that statistically financial distress has an influence to auditor switching. 


\section{REFERENCES}

Altman, E. I. 2000. Predicting Financial Distress of Companies; Revisiting the Z-score and Zeta Models. Journal of Banking and Finance 1(2); $1968-2000$.

Damayanti, S. dan M. Sudarma. 2008. "Faktor-Faktor yang Mempengaruhi Perusahaan Berpindah Kantor Akuntan Publik". Simposium Nasional Akuntansi XI, Pontianak, hal. 1-13.

DeFond, Mark L. 1992. The Association Between Changes in Client Firm Agency Costs and Auditor Switching. A Journal of Practice and Theory, Spring, Volume XI (1): 16-31.

Febrianto, Rahmat. Pergantian Auditor dan Kantor Akuntan Publik. 2009. artikel ini diakses tanggal 2 Februari 2013, dari http://rfebrianto.blogspot. com/2009/05/pergantian-auditor-dan-kantor akuntan.

Hudaib, M. dan T.E. Cooke. 2005. The Impact of Managing Director Changes and Financial Distress on Audit Qualification and Auditor Switching. Journal of Business Finance \& Accounting, Vol. 32, No. 9/10, pp. 1703-39.

Mutiara, Maida Sihombing. 2012. Analisis Hubungan Auditor - Klien : Faktor - Faktor Yang Mempengaruhi Auditor Switching”. Fakultas Ekonomika Dan Bisnis Universitas Diponegoro., Semarang.

Nasser, Abu T.; Wahid, Emelin A.; Nazri, Sharifah N. F. S. M. dan Hudaib, Mohammad. 2006. "AuditorClient Relationship: The Case of Audit Tenure and Auditor Switching in Malaysia":. Managerial Auditing Journal. Volume XXI (7): 724-737.

Nasser, et.al. 2006. "Auditor-Client Relationship: The Case of Audit tenure and Auditor Switching in Malaysia". Managerial Auditing Journal, Vol. 21, No. 7, pp. 724-737.

Pangky, Aloysius Wijaya. 2011. Faktor-Faktor Yang
Mempengaruhi Pergantian Auditor Oleh Klien. Jurusan Akuntansi Fakultas Ekonomi dan Bisnis Universitas Brawijaya., Vol 1, No 1. Semester 2012/2013.

Prastiwi, Andri dan Frenawidayuarti Wilsya. 2009 Faktor-faktor yang mempengaruhi pergantian auditor: Studi Empiris Perusahaan Publik di Indonesia. Jurnal Dinamika Akuntansi, Vol. 1, No. 1, pp. 62-75..

Pratitis, Yanwar Titi. 2012. Auditor Swtching: Analisis Berdasar Ukuran KAP, Ukuran Klien dan Financial Distress. Jurnal Akuntansi FE Universitas Negeri Semarang..

Sihombing, Maida Mutiara. 2012. Analisis Hubungan Auditor-Klien: Faktor-Faktor Yang Mempengaruhi Auditor Switching. Universitas Diponegoro.

Sudana, I. M. 2011. Manajemen Keuangan Perusahaan; Teori dan Praktek. Erlangga; Jakarta.

Suparlan and Wuryan Andayani, 2010. 'Analisis empiris pergantian kantor akuntan publik setelah ada kewajiban rotasi audit [Empirical analysis of the turn of the audit firm after no obligation audit rotation]'. Proceeding, Simposium Nasional Akuntansi XIII, Purwokerto, Indonesia.

Utami, Riska and Sirajuddin, Betri. 2014. Pengaruh Ukuran Kantor Akuntan Publik (KAP), Masa Perikatan dan Tekanan Waktu Terhadap Kualitas Audit (Studi Kasus KAP di Palembang). STIE MDP.

Wijaya, Aloysius Pangky. 2013. Faktor-Faktor Yang Mempengaruhi Pergantian Auditor Oleh Klien. Universitas Brawijaya.

Yanji Aurora, Neni., Djonet, S. and Sugeng, S., 2013. Peran Auditor BPKP dalam Mewujudkan Akuntabilitas Pelaksanaan APBD Kota Bengkulu (Doctoral dissertation, Fakultas Ilmu Sosial dan Ilmu Politik UNIB).

Yanwar Titi Pratitis. 2012. Auditor Switching: Analisis Berdasar Ukuran Kap, Ukuran Klien Dan Financial Distress" Accounting Analysis Journal 1 (1) (2012) 


\section{APPENDIX}

Table 1. Operasionalization of Variable

\begin{tabular}{|c|c|c|c|}
\hline No & Variable & Indicator & Scale Measurement \\
\hline 1 & $\begin{array}{l}\text { Client's Company Size } \\
\text { (Nasser et al., 2006) }\end{array}$ & $\begin{array}{l}\text { This client's firm size variable is calculated by performing natural logarithms } \\
\text { (Ln) over the total assets of the firm (Nasser et al., 2006) }\end{array}$ & Ratio \\
\hline 2 & $\begin{array}{l}\text { KAP's Firm Size (Estralita } \\
\text { dan Hansen, } 2009\end{array}$ & $\begin{array}{l}\text { Dummy variable, besides "The Big Four"Public Accountant Firm (1) and } \\
\text { "The Big Four" Public Accountant Firm(0) }\end{array}$ & Nominal \\
\hline \multirow[t]{2}{*}{3} & Client's Firm (Weston & \multirow{2}{*}{$\Delta \mathrm{S}=\frac{\text { St-St-1 }}{\mathrm{S}_{\mathrm{N}} 1}$} & \multirow[t]{2}{*}{ Ratio } \\
\hline & $\begin{array}{l}\text { and Copeland, } 1992 \text { in } \\
\text { Satriyo:2015) }\end{array}$ & & \\
\hline 4 & $\begin{array}{l}\text { Financial Distress (Nasser } \\
\text { et al, 2006) }\end{array}$ & $\mathrm{Z} "=6,56(\mathrm{WC} / \mathrm{TA})+3,26(\mathrm{RE} / \mathrm{TA})+6,72(\mathrm{EBIT} / \mathrm{TA})+1,05(\mathrm{BVE} / \mathrm{BVD})$ & Ratio \\
\hline 5 & $\begin{array}{l}\text { Auditor Switching (Prastiwi } \\
\text { and Wilsya, 2009) }\end{array}$ & $\begin{array}{l}\text { Dummy variable, 1value is given if the company replaces the Public } \\
\text { Accountant Firm, and } 0 \text { for the company that does not replace the Public } \\
\text { Accountant Firm }\end{array}$ & Nominal \\
\hline
\end{tabular}

